\title{
Bacterial culture and antibiotic sensitivity from the ocular conjunctiva of horses
}

\section{Ana Raquel de Araújo Ferreira ${ }^{1}$ Alana Fontenele Santana ${ }^{1}$ Ana Carolina da Veiga Rodarte de Almeida ${ }^{1}$ Renan Fiel Sousa ${ }^{2}$ Simone Perecmanis ${ }^{1}$ Paula Diniz Galera $^{{ }^{*}}$}

${ }^{1}$ Faculdade de Agronomia e Medicina Veterinária, Universidade de Brasília (UnB), Brasília, DF, Brasil. E-mail: dra.paulagalera@gmail.com. ${ }^{*}$ Corresponding author.

${ }^{2} 1^{\circ}$ Regimento de Cavalarias de Guarda (1º RCG), Setor Militar Urbano, 70631-901, Brasília, DF, Brasil.

ABSTRACT: The aim of this study was to identify the conjunctival bacterial flora of healthy horses in Brasilia (Distrito Federal, Brazil), and to evaluate the antimicrobial susceptibility of the isolated strains. We examined 200 eyes of 100 healthy adult horses without any eye problems, belonging to the 1st Regiment of the Cavalry Guard (RCG) of the Brazilian Army in Brasilia. Samples were collected from the inferior conjunctival fornix of both eyes. Drug

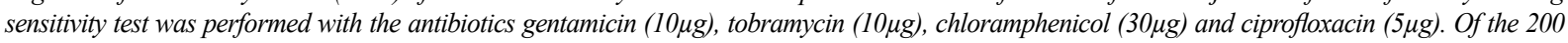
samples collected, 131 (65.5\%) were considered positive for bacterial growth. A total of 208 bacterial strains belonging to 19 genera were isolated, where there was prevalence of gram-positive bacteria (65\%), with Staphylococcus sp. being the species of greatest incidence. It was observed that 94 , 85 , 81 and $68 \%$ of the isolates were sensitive to ciprofloxacin, gentamicin, chloramphenicol and tobramycin, respectively. These results can guide the empirical selection antimicrobial therapy for infections of the ocular surface of horses, pending the identification of the etiologic agent. Key words: eye, horse, bacterial flora, antibiogram.

Cultura e sensibilidade bacteriana da conjuntiva ocular de equinos

RESUMO: Objetivou-se identificar a flora bacteriana conjuntival de cavalos saudáveis, residentes de Brasilia (Distrito Federal - Brasil), e avaliar a susceptibilidade antimicrobiana das cepas isoladas. Foram avaliados 200 olhos de 100 equinos hígidos, adultos, saudáveis e sem alterações oculares, provenientes do 1o Regimento de Cavalaria de Guarda (RCG) do Exército de Brasília. As amostras foram coletadas do fórnix conjuntival inferior de ambos os olhos. O teste de sensibilidade foi realizado para os antimicrobianos: gentamicina (10mcg), tobramicina (10mcg), cloranfenicol (30mcg) e ciprofoxacino (5mcg). Das 200 amostras coletadas, 131 (65,5\%) foram consideradas positivas para o crescimento bacteriano. Um total de 208 bactérias pertencentes a 19 gêneros foram isoladas, verificando-se prevalência de bactérias gram-positivas (65\%), sendo Staphylococcus sp, a espécie de maior incidencia. Foi observado que 94\%, 85\%, 81\% e 68\% das bactérias isoladas foram sensíveis ao ciprofloxacino, à gentamicina, ao cloranfenicol e à tobramicina, respectivamente. Tais resultados podem direcionar a escolha empirica da terapêutica antimicrobiana nas afecções da superficie ocular de equinos, enquanto se aguarda a identificação do agente etiológico.

Palavras-chave: olho, cavalo, flora bacteriana, antibiograma.

\section{INTRODUCTION}

The ocular surface is naturally inhabited by microorganisms that constitute its normal microflora. In different animal species, including horses (ANDREW et al., 2003; JOHNS et al., 2011), mules (TAMARZADEH \& ARAGHI-SOOREH, 2014), donkeys (FOTI et al., 2013), sheep (BONELLI et al., 2014), dogs (PRADO et al., 2005) and rabbits (ORIÁ et al., 2014). Bacterial population often isolated from healthy eyes is composed of gram-positive bacteria, although strains of methicillin-resistant to Staphylococcus (MRS) and gran negative strains, have also been identified (SANTOS et al., 2009; JOHNS et al., 2011; WILLCOX, 2013; MOUNEY et al., 2013).
Some eye infections, however, can be caused by resident microorganisms, which become potentially pathogenic after their virulence is increased by external factors, such as trauma, stress, aging and reduction in commensalmicrobiota(COGEN etal.2008; WILLCOX, 2013). Horses are probably more susceptible to corneal lesions, compared to other species, since they have bulging eyes susceptible to trauma associated with their physical activity and the environment where they live (PISANI et al., 1997; WADA et al., 2010).

Injury to the cornea, invaded by resident, pathogenic or potentially pathogenic microorganisms, leads to keratitis or infected corneal ulcers, which can be difficult to treat and can result in vision loss (MOORE et al. 1988; KURODA et al., 2015). 
Knowledge of the eye microflora of healthy horses allows us to establish a suitable antimicrobial therapy, which can be modified after obtaining the results of sensitivity tests, thereby reducing the development of antibiotic-resistant strains (SAUER et al., 2003; KELLER \& HENDRIX, 2005; TAMARZADEH \& ARAGHI-SOOREH, 2014). Accordingly, the aim of this study was to determine the conjunctival bacterial flora of healthy horses in Brasília (Distrito Federal Brazil), and to evaluate the antimicrobial susceptibility of the strains isolated to four antibiotics.

\section{MATERIALS AND METHODS}

The horses were randomly selected. We evaluated both eyes of 100 healthy horses, without any ocular or previous systemic alterations, adults (between 4 and 15 years old), 60 males and 40 females. Of these, 92 were of the Brasileiro de Hipismo breed and the others of different breeds; the horses belonged to the 1st Regiment of the Cavalry Guard (RCG) of the Brazilian Army in Brasília. All the horses were placed in similar individual bares, covered, with water and hay, and belonged to the same Regiment, located in the city of Brasilia.

For inclusion in this study, all animals were subjected to a routine ophthalmic examination, by a veterinarian with experience in ophthalmology, which was done on the same day as the collection of the samples for microbiological analysis.

Samples from the ocular conjunctiva for microbiological examination were collected with a sterile swab in the inferior conjunctival fornix of both eyes, avoiding touching the eyelashes or eyelids, and were placed test tubes with Stuart transport medium, which were sent to the Microbiology Laboratory of the Universidade de Brasília (UnB). Collections were done between the months of February and June, when the temperature was 16 to $25^{\circ} \mathrm{C}$ and the mean relative humidity was $73 \%$, according to the Instituto Brasileiro de Estudos Espaciais (INPE).

Samples were seeded in Petri dishes containing sterile 5\% sheep blood agar culture medium, and incubated at $37^{\circ} \mathrm{C}$ for 48 hours, under aerobic conditions. Plates that did not show bacterial growth within the incubation period were considered negative. After growth, the colonies were subjected to identification according to Gram staining and the use of biochemical tests of oxidation/fermentation glucose (OF), catalase, oxidase, $\mathrm{KOH}$, gelatin and urea.

The test for sensitivity to antibiotics was performed for all bacteria isolated using the disk diffusion assay. Each bacterial strain was inoculated in Mueller Hinton broth and incubated for $24 \mathrm{~h}$.
Bacterial suspension was seeded on the surface of a Muller Hinton agar plate, using sterile swabs, and paper disks impregnated with antibiotics were placed on the agar: gentamicin $(10 \mu \mathrm{g})$, tobramycin $(10 \mu \mathrm{g})$, chloramphenicol $(30 \mu \mathrm{g})$ and ciprofloxacin $(5 \mu \mathrm{g})$. Plates were incubated for $24 \mathrm{~h}$ in an incubator, and growth inhibition around each disk was then analyzed, classifying the bacteria as sensitive, intermediate or resistant to the antibiotic. The criteria for the choice of antimicrobials testes were based on the active principles most frequently used in the ophthalmic routine of horses in the Federal District, in addition, topical gentamicin and chloramphenicol are the antibiotics indicated for the preventive treatment of corneal ulcers in horses (SAUER et al., 2003; WADA et al., 2010; JOHNS et al., 2011), with chloramphenicol being still effective against strains of MRS, an emerging infection among equines (KURODA et al., 2015).

\section{RESULTS AND DISCUSSION}

In the literature, there is a variation of $52 \%$ to almost $100 \%$ with respect to the frequency of bacteria isolated from the ocular conjunctiva of horses without eye problems (VIDAL et al., 2010; JOHNS et al., 2011; FOTI et al., 2013; TAMARZADEH \& ARAGHI-SOOREH, 2014). Such discrepancy has been attributed to the ambient temperature and management to which the animal is subjected (PISANI et al., 1997; JOHNS et al., 2011); although, some authors have not identified any significant difference in the number or types of microorganisms isolated during different seasons of the year (ANDREW et al., 2003). Of the 200 samples collected in the present study, 131 $(65.5 \%)$ showed bacterial growth (Table 1$)$.

A total of 19 genera, of which 8 comprised gram-positive bacteria and 11 gram-negative bacteria, were identified in this study (Table 1). The grampositive bacteria displayed a predominance of $86.6 \%$ among the strains isolated, in accordance with findings for a series of domestic and wild animals (PRADO et al., 2005; SANTOS et al., 2009; SPINELLI et al., 2010; BONELLI et al., 2014; ORIÁ et al., 2014).

Staphylococcus sp. and Bacillus sp. are gram-positive microorganisms that make up part of the conjunctival microflora and the most frequent bacteria isolated from the ocular conjunctiva of horses without ophthalmic problems (VIDAL et al., 2010; FOTI et al., 2013; TAMARZADEH \& ARAGHI-SOOREH, 2014). This was also reported in the present study, where these genera represented 43 and $13 \%$ of the total strains isolated, respectively (Table 1). ANDREW et al. (2003), however, identified Corynebacterium as the most 
Table 1 - Bacteria isolated from the conjunctival fornix of 200 eyes of 100 healthy horses, given in quantity of samples isolated and percentage in relation to the whole sample.

\begin{tabular}{|c|c|c|c|c|}
\hline Bacteria & Cocci/Bacilli & Gram stain & No. of isolates & $\%$ of isolates \\
\hline Staphylococcus sp. & Cocci & Positive & 90 & 43.26 \\
\hline Bacillus sp. & Bacilli & Positive & 27 & 12.98 \\
\hline Rhodococcus equi & Cocci & Positive & 27 & 12.98 \\
\hline Corynebacterium sp. & Bacilli & Positive & 25 & 12.01 \\
\hline Actinomyces sp. & Cocci & Positive & 5 & 2.4 \\
\hline Micrococcus sp. & Cocci & Positive & 3 & 1.44 \\
\hline Listeria $s p$ & Bacilli & Positive & 2 & 0.96 \\
\hline Streptococcus sp. & Cocci & Positive & 1 & 0.48 \\
\hline Proteus mirabilis & Bacilli & Negative & 8 & 3.84 \\
\hline Pasteurella sp. & Cocci & Negative & 7 & 3.36 \\
\hline Flavobacterium sp. & Bacilli & Negative & 4 & 1.92 \\
\hline Francisella tularenses & Bacilli & Negative & 2 & 0.96 \\
\hline Acinetobacter sp. & Cocci & Negative & 1 & 0.48 \\
\hline Campylobacter sp. & Bacilli & Negative & 1 & 0.48 \\
\hline Enterobacter gergovial & Bacilli & Negative & 1 & 0.48 \\
\hline Enterobacteriace & Bacilli & Negative & 1 & 0.48 \\
\hline Haemophylus sp. & Bacilli & Negative & 1 & 0.48 \\
\hline Serratia liquefaciens & Bacilli & Negative & 1 & 0.48 \\
\hline Yersinia enterocolitica & Bacilli & Negative & 1 & 0.48 \\
\hline Total isolates & & & 208 & 100 \\
\hline Absent & & & 69 & \\
\hline
\end{tabular}

important genus in the ocular conjunctiva of healthy horses, followed by Staphylococcus and Bacillus. In the present study, Corynebacterium sp. was the fourth most common microorganism isolated, which has also been demonstrated in eyes of dogs (PRADO et al., 2005) and sheep (BONELLI et al., 2014) without eye problems, but at a lower prevalence as that observed in our animals.

Although staphylococcus are commensal bacteria in horses, some strains have acquired a greater pathogen potential by expressing a gene called mec, which encodes a binding protein to an altered penicilin, making the use of all beta-lactam antimicrobials used in veterinary medicine ineffective (MADDOX et al., 2015; VAN SPIJK et al., 2016). Colonization or infections specifically caused by methicillin-resistant Staphylococcus aureus (MRSA), has become a serious condition in equines, and a complex concern among animals, people and public health (TIROSH-LEVY et al., 2015, MADDOX et al., 2015, VAN SPIJK et al., 2016). In horses, several sites of MRSA infection have been reported, including skin, respiratory, urinary and reproductive tract (VAN SPIJK et al., 2016). MRSA-infected keratitis has been described in humans (ONGs et al., 2013) and dog (TAGIMA et al., 2013), and recently in a race mare resulting in a fatal condition (KURODA et al., 2015).

Methicillin-resistant Staphylococcus (MRS), however, are rarely isolated from healthy animals, but in those hospitalized, the prevalence is much higher (KURODA et al., 2016). In the present study, the search for MRS strains was not performed, but according to the researches published so far, healthy horses that have not undergone any recent surgical procedures and that are not under antibiotic treatment, are not predisposed to MRS infections.

ANDREW et al. (2003) identified Rhodococcus equi in the horse conjunctiva in five samples, representing only $0.2 \%$ of the total isolates. In our research, this bacterium was reported in 27 samples, where it accounted for $13 \%$ of the isolates identified. Rhodococcus equi and Corynebacterium $\mathrm{sp}$. are opportunistic bacteria, the optimal temperature for their development is about $30^{\circ} \mathrm{C}$, and the summer provides the climatic conditions that promote the multiplication of these microorganisms (KREWER et al., 2008), which can explain the high prevalence of these microorganisms in the present study and their absence in other reported studies.

Of the 11 genera of gram-negative bacteria identified, six belonged to the family Enterobacteriaceae, where the strain Proteus mirabilis was the most often isolated, representing $28.6 \%$ of all gram-negative bacteria isolated. Similar findings were respectively reported by SANTOS et al. (2009) and FOTI et al. (2013) in studies with dogs and horses with healthy eyes. JOHNS et al. (2011), meanwhile, reported the genus Acinetobacter as the most representative for the group 
of gram-negative bacteria, and did not identify Proteus mirabilis in their study. In accordance with these authors, we reported a high prevalence of Acinetobacter sp., probably due to the contamination of the environment around the horse's skin, besides being considered part of the normal microflora of the human skin.

Pseudomonas spp. is a gram-negative bacillus, considered as one of the most virulent pathogens of the cornea, with a prevalence between 6 and 14\% among the microorganisms identified in corneal ulcers of horses (SAUER et al., 2003; KELLER \& HENDRIX, 2005; WADA et al., 2010; WADA et al., 2010). As expected, this genus was not isolated in the present study; although, it was previously identified in the eyes of horses without ophthalmic problems (ANDREW et al., 2003; VIDAL et al., 2010; JOHNS et al., 2011).

A low prevalence of potential pathogens, such as Streptococcus sp. and strains of the family Enterobacteriaceae, such as Enterobacteriace and Serratia sp. were identified here, and previously isolated in horses with and without ocular pathologies (KELLER \& HENDRIX, 2003; ANDREW et al., 2003; JOHNS et al., 2011; TAMARZADEH \& ARAGHI-SOOREH, 2014). Both Streptococcus and Serratia are commensal microorganisms of the ocular conjunctiva of horses, but can become pathogenic and trigger diseases when colonizing wounds (SAUER et al., 2003; VIDAL et al., 2010).

Corneal infections and endophthalmitis caused by Streptococcus are not uncommon in horses and can be devastating (BROOKS et al., 2000). It is believed that Serratia sp. has the capacity to release proteases, resulting in liquefactive necrosis and corneal perforation (LYERLY et al., 1981). Since pathogenic bacteria are present in the environment, the low isolation of these microorganisms on the eye surface of horses in this study suggested that the normal flora can control or suppress colonization by pathogens.

Lesions on the ocular surface, with the formation of ulcerative keratitis, are frequent in horses, due to their anatomic particularities and activity (WADA et al., 2010; KURODA et al., 2015) and the immediate use of antibiotics is recommended to prevent the establishment of infections.

Antibiotics indicated for the preventive treatment of ulcers of the cornea in horses include topical gentamicin and chloramphenicol (SAUER et al., 2003; WADA et al., 2010; JOHNS et al., 2011). According to MATTHEWS (2009), gentamicin is effective against gram-positive (cocci) and gram-negative (cocci and bacilli) bacteria, while chloramphenicol is active only against gram-positive cocci. This was apparent in the present study, where the majority of the strains identified were gram-positive cocci, and these antimicrobials exhibited an efficacy of 85 and $81 \%$ against the bacterial isolates, respectively (Table 2). The same was not observed by TAMARZADEH \& ARAGHI-SOOREH (2014), reporting Staphylococcus, Bacillus, and Corynebacterium as the bacteria most often identified, with low efficacy of gentamicin and chloramphenicol.

$$
\text { KELLER \& HENDRIX (2003) }
$$

demonstrated a similar effectiveness as in our study, finding $78 \%$ of bacterial strains sensitive to gentamicin and chloramphenicol. These authors, along with WADA et al. (2010), reported that chloramphenicol was efficacious against all Streptococcus sp. isolates, which are gram-positive cocci, but not against Pseudomonas, while gentamicin was effective against both types of bacteria, corroborating the findings of Matthews (2009). In addition, chloramphenicol was effective against MRSA that contaminated keratitis in horses (KURODA et al., 2015). Despite the evident activity of gentamicin, resistance among microorganisms associated with keratitis in horses has been increasingly reported, as reported for Streptococcus sp. and Pseudomonas sp. (SAUER et al., 2003), and Staphylococcus aureus resistant to methicillin (MRSA) (KURODA et al., 2015).

Tobramycin was the least effective antibiotic against the bacteria identified, showing activity against $68 \%$ of the isolates, similar to KELLER \& HENDRIX (2003) studies, finding that only $41 \%$ of the microorganisms isolated were sensitive to tobramycin, despite showing high activity against Pseudomonas sp. WADA et al. (2010) observed 88\% efficacy with the use of tobramycin, but most of the bacterial isolates were Pseudomonas sp. In these two studies, tobramycin was ineffective against Streptococcus sp. Tobramycin has shown to be equally ineffective against methicillinresistant Staphylococcus aureus (MRSA), isolated from ulcerative keratitis in animals (KURODA et al., 2015). Such findings justify the prescription of this antibiotic in infections by gram-negative bacilli. Accordingly, the low bacterial sensitivity to tobramycin was expected, since the majority of the strains isolated here were gram-positive.

Ciprofloxacin belongs to fluoroquinolones class, which a broad spectrum of activity against grampositive and gram-negative organisms, and anaerobic microorganisms as well (SILVA \& HOLLENBACH, 2010), explaining its effectiveness in the present study, as observed by KELLER \& HENDRIX (2003), and also by SAUER et al. (2003) and WADA et al. (2010), but with the use of other fluoroquinolones. Ciprofloxacin should be reserved for severe cases, or infections where bacterial susceptibility is confirmed (SILVA and HOLLENBACH, 2010; WADA et al., 2010), because besides having a broad antimicrobial activity, it is known that its use inhibits the 
Table 2 - Sensitivity of bacteria, cultured from the ocular surface of healthy horse, to the different antibiotics given as percentage in relation to the isolates analyzed.

\begin{tabular}{|c|c|c|c|c|c|}
\hline Bacterium & No. of Isolates & Gentamicin & Tobramycin & Chloramphenicol & Ciprofloxacin \\
\hline Staphylococcus sp. & 90 & $85.6 \%$ & $76.7 \%$ & $85.5 \%$ & $96.7 \%$ \\
\hline Bacillus sp. & 27 & $81.5 \%$ & $70.4 \%$ & $77.8 \%$ & $92.6 \%$ \\
\hline Rhodococcus equi & 27 & $92.6 \%$ & $51.9 \%$ & $85.2 \%$ & $92.6 \%$ \\
\hline Corenybacterium sp. & 25 & $84 \%$ & $72 \%$ & $88 \%$ & $100 \%$ \\
\hline Proteus mirabilis & 8 & $100 \%$ & $87.50 \%$ & $75 \%$ & $100 \%$ \\
\hline Pasteurella sp. & 7 & $57.1 \%$ & $28.6 \%$ & $71.4 \%$ & $71.4 \%$ \\
\hline Actinomyces sp. & 5 & $100 \%$ & $60 \%$ & $40 \%$ & $100 \%$ \\
\hline Flavobacterium sp. & 4 & $25 \%$ & $25 \%$ & $25 \%$ & $25 \%$ \\
\hline Micrococcus sp. & 3 & $66.7 \%$ & $66.7 \%$ & $66.7 \%$ & $100 \%$ \\
\hline Listeria $\mathrm{sp}$ & 2 & $100 \%$ & $100 \%$ & $50 \%$ & $100 \%$ \\
\hline Francisella tularenses & 2 & $100 \%$ & $50 \%$ & $50 \%$ & $100 \%$ \\
\hline Acinetobacter sp. & 1 & $100 \%$ & $100 \%$ & $100 \%$ & $100 \%$ \\
\hline Campylobacter sp. & 1 & $100 \%$ & $0 \%$ & $100 \%$ & $100 \%$ \\
\hline Enterobacter gergovial & 1 & $100 \%$ & $0 \%$ & $100 \%$ & $100 \%$ \\
\hline Enterobacteriace & 1 & $100 \%$ & $0 \%$ & $100 \%$ & $100 \%$ \\
\hline Haemophylus sp. & 1 & $100 \%$ & $100 \%$ & $100 \%$ & $100 \%$ \\
\hline Serratia liquefaciens & 1 & Inconclusive & Inconclusive & Inconclusive & Inconclusive \\
\hline Streptococcus sp. & 1 & $100 \%$ & $100 \%$ & $100 \%$ & $100 \%$ \\
\hline Yersinia enterocolitica & 1 & $100 \%$ & $100 \%$ & $100 \%$ & $100 \%$ \\
\hline Total percentage of sensitive isolates & 208 & $84.6 \%$ & $68.3 \%$ & $80.8 \%$ & $93.8 \%$ \\
\hline
\end{tabular}

migration of epithelial cells in the cornea, which can compromise wound healing (HENDRIX et al., 2001).

Although we have evaluated an expressive number of animals, as the horses came from the same place and are exposed to similar environmental conditions, we should consider that our results have not the same approach for animals from different regions. We encourage studies involving samples from all regions of our country.

\section{CONCLUSION}

The identification of the normal microflora of the ocular conjunctiva from horses, and their sensitivity to the antimicrobials used in the current study is important because it helps the clinicians to find the correct course of prophylactic treatment in case of corneal ulcer, until the results of the culture and antibiogram are available, which can take days, and consequently result in vision loss, especially if appropriate antimicrobial treatment is delayed, and/or performed with inappropriate antibiotics.

\section{BIOETHICS AND BIOSSECURITY COMMITTEE APPROVAL}

The study was submitted to and approved by the Committee of Ethics and Use of Animals of the Universidade de Brasília (protocol No. 153838/2014), and in accordance with the ethics principles of ARVO (Statement for the Use of Animals in Ophthalmic and Vision Research).

\section{ACKNOWLEDGEMENTS}

To Coordenação de Aperfeiçoamento de Pessoal de Nível Superior (CAPES) and DROGAVET - Brasília, DF, for the Schirmer tear test and fluorescein strips.

\section{REFERENCES}

ANDREW, S. E. et al. Seasonal effects on the aerobic bacterial and fungal conjunctival flora of normal thoroughbred brood mares in Florida. Veterinary Ophthalmology, v.6, n.1, p.45-50, 2003. Available from: <http://dx.doi.org/10.1046 /j.1463-5224.2003.00265.x>. Accessed: Feb. 20, 2016. doi: 10.1046/j.1463-5224.2003.00265.x.

BONELLI, F. et al. Conjunctival bacterial and fungal flora in clinically normal sheep.Veterinary Record, v.1, n.1,p.1-4, 2014. Available from: $<$ http://vetrecordopen.bmj.com/content/1/1/e000017.full.pdf+html> . Accessed: Feb. 20, 2016. doi: 10.1136/vropen-2013-000017.

BROOKS, D.E. et al. Ulcerative keratitis caused by beta-hemolytic Streptococcus equi in 11 horses. Veterinary Ophthalmology, v.3, n.2-3. p.121-125, 2000. Available from: $<$ htpp://dx.doi.org/10.10 46/j.1463-5224.2000.3230121.x>. Accessed: Mar. 10, 2016. doi: 10.1046/j.1463-5224.2000.3230121.x.

COGEN, A.L. et al. Skin microbiota: a source of disease or defense? British Journal of Dermatology, v.158, n.3, p.442-455, 2008. Available from: $<$ http://www.ncbi.nlm.nih.gov/pmc/articles/ PMC2746716/pdf/nihms91877.pdf >. Accessed: Mar. 10, 2016. doi: $10.1111 / \mathrm{j} .1365-2133.2008 .08437 . x$.

FOTI, M. et al. Detection of methicillin-resistant Staphylococcus aureus (MRSA) in the microbial flora from the conjunctiva of healthy donkeys from Sicily (Italy). Veterinary Ophthalmology, v.16, n.2, p.89-92, 2013. 
Available from: $<$ http://dx.doi.org/10.1111/j.1463-5224.2012.01028.x > . Accessed: Feb. 22, 2016. doi: 10.1111/j.1463-5224.2012.01028.x.

HENDRIX, D.V.H. et al. Effects of antibiotics on morphologic characteristics and migration of canine corneal epithelial cells in tissue culture. American Journal of Veterinary Research, v.62, n.10, p.1664-1669, 2001. Available from: <http://www.ncbi.nlm. nih.gov/pubmed/11592337>. Accessed: Mar. 12, 2016.

JOHNS, I.C. etal.Conjunctival bacterial and fungal flora in healthy horses in the UK. Veterinary Ophthalmology, v.14, n.3, p.195-199, 2011. Available from $<\mathrm{htpp} / / / \mathrm{dx}$.doi.org/10.1111/j.1463-5224.2010.00867.x> . Accessed: Mar. 15, 2016. doi: 10.1111/j.1463-5224.2010.00867.x.

KELLER, R.L.; HENDRIX, D.V.H. Bacterial isolates and antimicrobial susceptibilities in equine bacterial ulcerative keratitis. Equine Veterinary Journal, v.37, n. 3, p. 207-211, 2005. Available from: <http://dx.doi.org/10.2746/0425164054530731>. Accessed: Feb. 22, 2016. doi: 10.2746/0425164054530731.

KREWER, C.C.et al. Rhodococcus equi. Arquivos do Instituto Biológico, v.75, n.4, p.533-545, 2008. Available from: <http:// www.biologico.sp.gov.br/docs/arq/v75_4/krewer.pdf>. Accessed: Feb. 22, 2016.

KURODA, T. et al. Methicillin-resistant Staphylococcus aureus ulcerative keratitis in a Thoroughbred racehorse. Journal Equine Science, v.26, n.13, p.95-98, 2015. Available from: <http://doi. org.sci-hub.cc/10.1294/jes.26.95>. Accessed: Oct. 25, 2016. doi: 10.1294/jes.26.95.

LYERLY. D. et al. Characterization of rabbit corneal damage produced by Serratia keratitis and by Serratia protease. Infection and Immunity, v.33, n.3, p.33:927-932, 1981. Accessed: Mar. 12, 2016. Available from: $<$ http://iai.asm.org/content/33/3/927.long $>$.

MADDOX. T.W. et al. Antimicrobial resistance in bacteria from horses: epidemiology of antimicrobial resistance. Equine Veterinary Journal, v.47, n. 6, p. 756-765, 2015. Available from: $<$ http://onlinelibrary.wiley.com/doi/10.1111/evj.12471/epdf $>$. Accessed: Oct. 25, 2016. doi: 10.1111/evj.12471.

MATTHEWS A.G. Ophthalmic antimicrobial therapy in the horse. Equine Veterinary Education, v.21, n.5, p.271-289, 2009. Available from: <http://dx.doi.org/10.2746/095777308X334266>. Accessed: Feb. 20, 2016. doi: 10.2746/095777308X334266.

MOUNEY, M.C. et al. Prevalence of methicillin-resistant Staphylococcus spp. in the conjunctival sac of healthy dogs. Veterinary Ophtalmology, v.18, n.2, p.123-126, 2015. Available from: <https://www.ncbi.nlm.nih.gov/pubmed/24299189>. Accessed: Nov. 06, 2016. doi: 10.1111/vop.12130.

ORIÁ, A.P. et al. Tear production, intraocular pressure and conjunctival microbiota, cytology and histology of New Zealand rabbits (Oryctolagus cuniculus). Pesquisa Veterinária Brasileira, v.34, n.10, p.1024-1028, 2014. Available from: <http://www. scielo.br/pdf/pvb/v34n10/16.pdf>. Accessed: Mar. 10, 2016. doi: 10.1590/S0100-736X2014001000016.

PISANI, E.H.R. et al. Microbiota conjuntival normal de equinos. Brazilian Journal of Veterinary Research and Animal Science, v.34, n.5. p.261-265, 1997. Available from: <http://revistas.bvs-vet. org.br/bjvras/article/download/2890/2127>. Accessed: Mar. 12, 2016.
PRADO, M.R. et al. Survey of bacterial microorganisms in the conjunctival sac of clinically normal dogs and dogs with ulcerative keratitis in Fortaleza, Ceará, Brazil. Veterinary Ophthalmology, v.8, n.1, p.33-37, 2005. Available from: $<\mathrm{http} / / / \mathrm{dx}$.doi.org/http://dx.doi.org /10.1111/j.1463-5224.2005.04061.x>. Accessed: Mar. 12, 2016. doi: 10.1111/j.1463-5224.2005.04061.x.

SANTOS, L.G.F. et al. Conjunctival microbiota of healthy dogs with ophthalmic conditions Microbiota conjuntival de cães hígidos e com afecções oftálmicas. Acta Scientiae Veterinariae, v.37, n.2, p.65-169, 2009. Available from: $<$ http://www.ufrgs.br/actavet/37-2/art826.pdf $>$. Accessed: Mar. 10, 2016. doi: 10.5216/cab.v14i4.19210.

SAUER, P. et al. Changes in antibiotic resistance in equine bacterial ulcerative keratitis (1991-2000): 65 horses. Veterinary Ophthalmology, v.6, n.4, p.309-313, 2003. Available from: <http:// onlinelibrary.wiley.com/doi/10.1111/j.1463-5224.2003.00312.x/full> . Accessed: Mar. 12, 2016. doi: 10.1111/j.1463-5224.2003.00312.x.

SILVA, J.M.B.; HOLLENBACH, C.B. Fluoroquinolonas x resistência bacteriana na Medicina Veterinária. Arquivos do Instituto Biológico, v.77, n.2, p.363-369, 2010. Accessed: Mar. 10, 2016. Available from: $<$ http://www.biologico.sp.gov.br/docs/arq/v77_2/silva1.pdf $>$.

SPINELLI, T.C. et al. Normal aerobic bacterial conjunctival flora in the Crab-eating raccoon (Procyon cancrivorus) and Coati (Nasua nasua) housed in captivity in Pernambuco e Paraiba (Northeast, Brazil). Veterinary Ophthalmology, v.13, Suppl., p.134-136, 2010. Available from: <http://dx.doi.org/10.1111/j.1463-5224.2009.00728. x>. Accessed: Mar. 10, 2016. doi: 10.1111/j.1463-5224.2009.00728.x.

TAMARZADEH, A.; ARAGUI-SOOREH, A. Bacterial flora of the conjunctiva in healthy mules. Reveu MédicineVéterinaire, v.165, n. 11-12, p.334-337, 2014. Available from: <www.revmedvet. com/2014/RMV165_334_337.pdf>. Accessed: Mar. 10, 2016.

TIROSH-LEVY. S. Prevalence and risk factors for colonization with methicillin resistant Staphylococcus aureus and other Staphylococci species in hospitalized and farm horses in Israel. Preventive Veterinary Medicine, v.122, p. 135-144, 2015. Available from: $<$ http://dx.doi.org/10.1016/j.prevetmed.2015.09.007>. Accessed: Oct. 25, 2016. doi: 10.1016/j.prevetmed.2015.09.007.

VAN SPIJK. J.N. et al. A retrospective analysis of antimicrobial resistance in bacterial pathogens in an equine hospital (2012-2015). Schweiz Archiv Tierheilkd, v.158, n.6, p. 33-442,2016. Available from: $<$ http://www.gstsvs.ch/fileadmin/media/pdf/SAT_open/SAT_06_2016_ van_Spijk_2.pdf $>$. Accessed: Oct. 25, 2016. doi: $10.17236 /$ sat00068.

VIDAL, G.H et al. Localización de Serratia marcescens em perfil bacteriológico y fúngico de la conjuntiva de caballos clinicamente sanos en Monterrey, Nuevo León, México. Veterinaria México, v.41, n.4, p.239-249, 2010. Accessed: Mar. 12, 2016. Available from: $<$ http://www.scielo.org.mx/pdf/vetmex/v41n4/v41n4a1.pdfs.

WADA, S. et al. Ulcerative keratitis in throughbred racehorses in Japan from 1997 to 2008. Veterinary Ophthalmology, v.13,p.99-105, 2010. Available from: $<$ http://dx.doi.org/10.1111/j.1463-5224.2010.00767. x>. Accessed: Feb. 22, 2016. doi: 10.1111/j.1463-5224.2010.00767.x.

WILLCOX, M.D.P. Characterization of the normal microbiota of the ocular surface. Experimental Eye Research, v.117, p.99-105, 2013. Available from: <http://dx.doi.org/10.1016/j.exer.2013.06.003>. Accessed: Mar. 10, 2016. doi: 10.1016/j.exer.2013.06.003. 